\title{
The survival mechanism of Home Industries (UMKM) of poor families after a disaster
}

\author{
Mekanisme survival UMKM keluarga miskin pasca terjadinya bencana
}

\author{
Udji Asiyah \\ Department of Sociology, Faculty of Social and Political Sciences, Universitas Airlangga \\ Jalan Dharmawangsa Dalam Selatan, Surabaya, East Java 60286 \\ E-mail: udji.asiyah@fisip.unair.ac.id
}

\begin{abstract}
The numerous forms of dependent $U M K M$ s actors and their financial deficit, as well as the threat of poverty, should be prevented by using the substitute institutions that will be able to fulfill the needs of $U M K M \mathrm{~s}$ in terms of capital, fulfilment of raw materials and marketing activities. The flood of Bengawan Solo River is often served as an annual problem faced by the $U M K M$ in the disaster prone areas. The aim of this research is to formulate contextual intervention policies and programs, especially for community empowerment of home industries $(U M K M)$ actors who are the disasters victims. This research used quantitative method. The data collection technique is interview with the total number of respondents 100 poor families who rely on their daily lives from business industries (UMKM) and in-depth interview to the ten selected informants. Among the $U M K M$ actors who are looking for capital loans for new business start-up, seems to be the most common way to survive. When the prospect to expand the business is believed to be still there, then a respondent will try to rebuild his business from the bottom. However, when they feel there is no opportunity to restart their businesses, then the mechanism is trying to find another job to survive the survival of his family. The efforts to empower UMKM in disaster prone areas cannot be done by relying on a charitable programs and activities, but most importantly is how to awaken, give opportunities and empower UMKM actors in the real sense.
\end{abstract}

Keywords: disaster; $U M K M$; survival mechanism

\begin{abstract}
Abstrak
Berbagai bentuk ketergantungan pelaku UMKM dan defisit keuangan serta ancaman kemiskinan yang mereka alami, harus dicegah dengan menggunakan lembaga pengganti yang mampu memenuhi kebutuhan para pelaku UMKM, baik di bidang permodalan, pemenuhan bahan baku dan pemasaran. Banjir Bengawan Solo adalah banjir yang terjadi setiap tahun yang dihadapi oleh UMKM yang berada di wilayah tersebut. Tujuan dari penelitian ini adalah untuk memformulasikan kebijakan dan program intervensi yang kontekstual, terutama untuk pemberdayaan komunitas dari pelaku UMKM yang menjadi korban bencana. Penelitian ini menggunakan metode kuantitatif. Teknik pengumpulan data yang digunakan adalah wawancara responden dengan jumlah 100 keluarga dan indepth interview dilakukan terhadap 10 informan terpilih. Bagi pelaku UMKM yang mencari pinjaman modal untuk membangun bisnis baru adalah cara umum untuk bertahan. Ketika prospek untuk mengembangkan bisnis masih ada, kemudian responden akan mencoba untuk membangun kembali bisnisnya dari bawah. Namun, ketika mereka merasa bahwa tidak ada kesempatan untuk memulai kembali bisnisnya, maka mekanisme bertahan yang mereka lakukan adalah mencari pekerjaan baru. Usaha untuk memberdayakan UMKM di wilayah rentan bencana tidak bisa dilakukan hanya dengan program dan kegiatan amal, tetapi yang terpenting adalah bagaimana menghidupkan kembali, memberikan kesempatan dan memberdayakan pelaku UMKM dalam arti yang sebenarnya.
\end{abstract}

Kata kunci: bencana; UMKM; mekanisme survival

\section{Introduction}

When a disaster strikes, whether it is a flood, a landslide or a volcanic eruption, one of the inevitable consequences is that some local people will be the victims of a disaster that causes them to suffer a terrible time. A family whose house is damaged, its land is inundated, sand dumped, or its business is forced to halt its production process, so do not be surprised what will happen afterward is the process of deepening of poverty and the loss of the bread-winner of family economy. A family who manage a home industries $(U M K M)$, when they become victims of disaster, then their production activities 
will automatically stop, and when the capital is absorbed to spend their daily lives during a disaster, then to revive the business they were managed undoubtedly not an easy thing.

A study done by Mustain \& Asiyah (2014) that examines the impact of floods among poor communities along the Bengawan Solo basin found that the overflowing of the Bengawan Solo river not only generates worsening poverty and economic life of families, and the process of deepening poverty, but also causing poor families to lose their production assets as well as their home to be damaged that ultimately cause their debt to increase. Many poor families as the victims from the disaster then stopped their business, the capital lost, and even some of them had to change jobs, migrate to try to find a job in the big city.

The research conducted by Firdaus (2011) to the victims of Situ Gintung revealed that the disaster could cause the society lose their business and work. Therefore, they have to ask help and borrow some money from their neighbours to do their business until the people ask for assistance to the social institutions such as dompet dhuafa.

A study by Mustain \& Asiyah (2014) found that floods struck in the disaster-prone areas such as Bojonegoro and Lamongan districts often resulted in poor families being cropped, losing their production assets, disrupted daily life due to unstoppable water logging, the disease begins to develop, the debt increases and ultimately the lives of poor families become more miserable because of the process of deepening poverty. The rainy season, for poor families who are victims of disasters, are often times of concern, and even miserable because they are likely to experience increasingly chronic pressures of poverty. To overcome the disasters that happened, watershed management should be observed because it has a strategic role as one of the natural resources that support the life of the people around it (Suganda 2009).

According to Hendrawan (2005), flood disaster that happened in Bojonegoro and Lamongan District caused by the watershed overflowing because of the increase of population density around that area. Besides it also caused be an increased the utilization or natural resource exploitation intensively, which makes the degradation of watershed area severe.

According to Adi (2013) flood mitigation efforts can be done with several approaches, namely early warning system, identification of flood hazard zones and community preparedness, which consists of strengthening themselves as well as avoid danger areas and capable to live in harmony with the danger. From the government side, disaster management is carried out by covering the disaster prevention, emergency response, rehabilitation and reconstruction in a fair and equal manner which based on community (Habibullah 2013), as well as raise disaster awareness for the society (Srihartini 2010).

The society who lives in the disaster-prone area must be ready for the coming disaster since that it will bring economic losses to them. Such as their SMEs threatened with the bankruptcy. However, most of the society prefer to choose to stay in that area. As the society who lives along with Bengawan Solo watershed in Bojonegoro and Lamongan, although almost every year they will experience flood disaster, they still stay and lives there. This is because they have another reason such as the fertility of soil, local wisdom, their place of birth and live, which makes them prefer to live side by side with the disaster risks (Habibi 2013).

In the short term, these poor families who are the victims of the disasters usually make austerity measures such as asking for relatives help, rely on debt or tighten belts to fulfil the needs of life during or after the disaster. To the extent possible, the victims of the disasters usually will try to find a job, work harder and try to revive the business they have managed before. The debt itself, is often the most realistic way to deal with the needs of life that cannot be delayed again. However, debt is often also a trap that opens the possibility of poor families entering the vortex of poverty that making the poor families to very poor conditions. A poor family that depend their daily lives from home industries (UMKM), will be threatened a bankruptcy, so that they have to start pioneering new business for depend their lives on and continue living as well as supporting their family. 
Among the families victims of the disaster, the problems that have not been studied in previous research, and therefore it is interesting to be studied further are the problems and how the efforts developed by poor families who rely on home industries $(U M K M)$ to revive their production activities after the disaster. For instance a farmer suffering from crop failure when his rice field is inundated by floods as well as his difficulties if he wants to restart cultivating his rice field because he does not have sufficient capital, poor families who work on micro, small and medium enterprises (UMKM) often experience difficulties when the place of business and production activities are forced to stop because of a disaster. For instance, a business actor of $U M K M$ who had stopped his production for one month, are most likely to lose his customers, because the place where they sell the commodity and produce it has been replaced by other home industries (UMKM).

The results of this study are expected not only to increase the diversity of studies on the people who are as the victims of the disasters, but at the same time also be a reference for the East Java Provincial Government in formulating contextual intervention policies and programs, especially for community empowerment of home industries (UMKM) actors who are victims of disasters.

\section{Research Method}

This research employed quantitative method. The research locations set in two areas, namely: District Bojonegoro, Bojonegoro and Laren Sub-district Lamongan. These two areas are chosen because the flood in these areas are likely to happen annually due to the overflowing of the Bengawan Solo River.

In each regency, in this study 50 families victims of the disaster had interviewed, the total number of respondents are 100 poor families who rely on their daily lives from business industries (UMKM). The criteria of the interviewed respondents were: (1) have a family and live in the research location, and (2) In the past one year have been victims of Bengawan Solo flood disaster. The families studied here were those whose business had stalled because of the location of his business had been flooded Bengawan Solo River or had stopped because the capital runs out to live during a disaster as the victim.

For in-depth interviews in this study have been conducted on ten selected informants. The informants who has been interviewed were local community leaders, such as the head of RT / RW, headman, and community leaders who knew and had many years of experience in facing the socio-economic impact of the disaster. Interviews guided by pre-prepared research instruments. In-depth interviews with some of these informants need to be done to obtain more detailed information about the eruption of Merapi volcano and floods that routinely experienced by local residents at the study site.

This study also collected and analyzed secondary data on the flood disaster of Bengawan Solo River Basin as well as socio-economic condition of the community in the location of the conducted study. Secondary data are searched in Bappeda and BPS. All the data collected, has been tabulated, processed and analyzed refer to the theoretical framework that has been written. At the end of the report, besides showing the finding priority issues of this study, it also presented strategies as well as intervention programs needed to support the efforts of re-empowering home industries (UMKM) actors who are the victims of the disasters. Recommended strategies and programs, all compiled and arranged refer to the findings of the data obtained, thus a contextual results will be completely suggested in the end.

\section{Result and Discussion}

\section{Pressure and process of deepening poverty}

For the people living in the village, the disaster they experienced in the last two years is not only a flooding threat due to the overflowing of the Bengawan Solo River, but also the drought of uncertain climate change. El Nino and La Nina which occurs in East Java, have resulted in prolonged drought, so that during the rainy season people suffer from flooding, while when the dry season comes, the threats change into drought and climate changes that tend to be anomalous. 
In the past two years, all respondents stated that they were generally affected by floods due to the overflowing of the Bengawan Solo River. In fact, as many as $91 \%$ percent of respondents admitted their homes experienced floods 1 to 2 times. A total of $6 \%$ of respondents said their homes had experienced floods 3 to 4 times in the past two years or on average twice a year.

Table 1.

Intensity of the flood and its impact

\begin{tabular}{cccc}
\hline & & $1-2$ & $91 \%$ \\
& & $3-4$ & $6 \%$ \\
In the last two years, the & Flooded houses & $<5$ & $0 \%$ \\
\cline { 2 - 3 } respondent experienced flood & & Never & $28 \%$ \\
disaster due to overflowing of & & $72 \%$ \\
Bengawan Solo River several & & 0 \\
times & Farm flooded (N:72) & $3-4$ & 0 \\
& & $<5$ & $28 \%$ \\
The family economic & The worse & $72 \%$ \\
condition in the aftermath & Relatively the same & $0 \%$ \\
\hline
\end{tabular}

A total of 72 respondents stated that besides their homes, their rice fields are also flooded. For the respondents who work as farmers as well as home industry actors, the flood that inundated their fields is certainly very harmful, because it causes these farmers lost their opportunities to harvest the crops. The flooded rice fields, not only damage the rice paddy as well as the palawija plants that the farmers have planted, but also the expectation of the respondents to harvest and reap their work.

Table 2.

The type of disaster that has been experienced in the last two years

\begin{tabular}{lcccc}
\hline \multicolumn{1}{c}{ The intensity of occuring } & $\mathbf{1 - 2}$ times & $\mathbf{3 - 4}$ times & $\mathbf{5 - 6}$ times & More than $\mathbf{7}$ times \\
\hline Flood due to overflowing river & $97 \%$ & $3 \%$ & 0 & 0 \\
Flood due to heavy rain & $87 \%$ & $13 \%$ & 0 & 0 \\
Typhoon & $0 \%$ & $0 \%$ & $0 \%$ & $0 \%$ \\
Drought & $91 \%$ & $9 \%$ & $0 \%$ & $0 \%$ \\
\hline
\end{tabular}

In the last two years, the type of disaster that has been experienced by the respondents were drought. As many as $97 \%$ of respondents admitted to ever 1-2 times experiencing flooding due to overflowing Bengawan Solo River. As many as $87 \%$ of respondents claimed to have experienced floods due to continuous heavy rain. As many as $91 \%$ of respondents admitted aside than flood, they also experienced a drought in the dry season. For farmers who rely on rain-fed systems, prolonged drought disasters, would make it difficult for respondents to reap the best harvest. In fact, it is possible that their chances of harvesting become annihilated when the dry season seems to be interminable (Table 2).

What are the material losses suffered and should be borne by respondents when they experience a flood disaster or other disaster? When this question was asked, most respondents claimed the most severe material losses were generally the damage to their productive assets. As many as $50 \%$ of respondents said their production assets were damaged due to the flood disaster. Meanwhile, as many as $37 \%$ of respondents said their asset damage is quite severe, and the remaining $13 \%$ of respondents said the damage to their assets is not too severe despite being a victim of flooding (Table 3 ).

Of the 100 families studied, the study found that losses suffered by floods, not only the damage of their production assets, but also the reduce of their saving or even lost. A total of $13 \%$ of respondents said their savings were depleted a lot during the flood disaster. A total of $39 \%$ of respondents said their savings were reduced considerably, and only $33 \%$ of respondents stated their savings were reduced - though not much (Table 3 ). 
Table 3.

Material loss occurred

\begin{tabular}{lcccc}
\hline \multicolumn{1}{c}{ Material Loss } & Yes, severe & $\begin{array}{c}\text { Yes, quite } \\
\text { severe }\end{array}$ & $\begin{array}{c}\text { Yes, not that } \\
\text { severe }\end{array}$ & No \\
\hline Family member are sick & $4 \%$ & $10 \%$ & $21 \%$ & $65 \%$ \\
Forced to move house & $7 \%$ & $0 \%$ & $0 \%$ & $93 \%$ \\
Debt Increase & $2 \%$ & $28 \%$ & $41 \%$ & $29 \%$ \\
Saving reduce or lost & $13 \%$ & $39 \%$ & $33 \%$ & $14 \%$ \\
The productive asset damaged & $50 \%$ & $37 \%$ & $13 \%$ & $0 \%$ \\
\hline
\end{tabular}

As a result of the flood disaster, most respondents stated that they are usually forced to borrow to cover urgent life needs. A total of $28 \%$ of respondents said their debt is quite a lot, and $41 \%$ of respondents said still have the debt even though the amount is not much. Of the 100 respondents, $2 \%$ of respondents said their debts jumped dramatically after the disaster (Table 4).

Table 4.

The total losses and the prone season that is disadvantageous for the respondents family

\begin{tabular}{|c|c|c|}
\hline \multirow{5}{*}{$\begin{array}{l}\text { Estimated, how much total cost/damage/loss do } \\
\text { you (sir/madam) have to responsible due to floods } \\
\text { that you have ever experienced }\end{array}$} & $0-500.000$ & $28 \%$ \\
\hline & $500.001-1.000 .000$ & \\
\hline & & $19 \%$ \\
\hline & $1.000 .001-1.500 .000$ & $41 \%$ \\
\hline & $<1.500 .001$ & $12 \%$ \\
\hline \multirow{3}{*}{$\begin{array}{l}\text { In what season does it usually more prone to } \\
\text { disadvantageous disaster }\end{array}$} & Rainy Season & $28 \%$ \\
\hline & Dry Season & $31 \%$ \\
\hline & The Same & $51 \%$ \\
\hline
\end{tabular}

From the disaster experienced by the respondents, it is estimated that the total loss is that they have to cover may not be too much. As many as $41 \%$ of respondents claimed to bear losses of about 1 million to 1.5 million rupiah. Of the 100 families studied, $28 \%$ of respondents claimed to bear losses below 500 thousand, and $19 \%$ about 500 thousand to 1 million rupiah. Only 12\% of respondents claimed to bear losses of up to 1.5 million rupiah (Table 4 ).

For those respondents who have sufficient savings, to bear the burden of losses of up to 1-2 million dollars may not be too much of a problem, but for poor families who struggle in providing their daily needs, when they have to lose production assets and bear the loss of money to millions of dollars, of course this burden becomes very burdensome. It is burdensome, because the money they could have used to add to the accumulation of capital and investment, eventually disappeared just because of disaster all of the sudden.

For most respondents (51\%), the burdens and losses they have to bear, both due to flood and drought are generally no different. Nevertheless, $31 \%$ of respondents said it was heavier in the dry season, and $28 \%$ of respondents stated heavier in the rainy season.

\section{Capital eradication and the recovery efforts of home industries actors (UMKM)}

The annual disasters that strike among people living along in the Bengawan Solo River Basin, although it has been anticipated, but it is always have inevitable impact. Among home industries $(U M K M)$ actors, the occurrence of flood disaster not only damage their assets and business land, but also resulted in the process of eroding their venture capital. This study found, that due to the flood, what most of the home industries $(U M K M)$ actors have to cover is the destruction of business 
sites which is the core income for the respondents. Out of 100 home industries actors surveyed, $26 \%$ of respondents stated their business sites were damaged by flooding, and 19\% of respondents said the damage was quite severe, while $40 \%$ of respondents stated that the damage of the business site caused by the flood is not severe (Sesunan 2014).

Table 5.

The impact of the disaster to the business manage

\begin{tabular}{lcccc}
\hline \multicolumn{1}{c}{ Impact of the disaster } & $\begin{array}{c}\text { Yes, } \\
\text { severe }\end{array}$ & $\begin{array}{c}\text { Yes, quite } \\
\text { severe }\end{array}$ & $\begin{array}{c}\text { Yes, not } \\
\text { that severe }\end{array}$ & No \\
\hline The business that temporarily stopped & $4 \%$ & $15 \%$ & $19 \%$ & $62 \%$ \\
Damaged/Loss production material & $10 \%$ & $21 \%$ & $24 \%$ & $45 \%$ \\
The site damaged & $26 \%$ & $19 \%$ & $40 \%$ & $16 \%$ \\
The decreasing of the turnover & $0 \%$ & $38 \%$ & $29 \%$ & $33 \%$ \\
The decreasing of the target market & $28 \%$ & $41 \%$ & $12 \%$ & $19 \%$ \\
The increasing of the production cost & $19 \%$ & $50 \%$ & $19 \%$ & $12 \%$ \\
Eradication of the capital & $20 \%$ & $76 \%$ & $4 \%$ & $0 \%$ \\
\hline
\end{tabular}

Except for the destruction of the business sites that have to be experienced by the small business actors, the other crucial things that happened is the drastic decreasing of the targeted market. A total of $28 \%$ of respondents said their market share of the products decreased drastically due to the disaster, while $41 \%$ of respondents said the market share decrease is felt after the disaster. As the actors of $U M K M$ whose market share is limited, and most are the surrounding communities, it is natural that the consumers of the products they produce decline drastically because of the flood disaster. Fellow citizens who are both suffering from flooding, some are displaced, others are busy keeping and repairing their submerged homes. In this kind of situation, it is only natural that the people who become the actors of the UMKM along the Bengawan Solo River Basin are temporarily losing their buyers.

As the actors of $U M K M$ who has a limited market and most of their consumer is the people who live near their business place, it is reasonable when the consumer of their products drastically decreasing because of the flood disaster. The people were suffering together because of the flood, some people were evacuated themselves, other people busy to take care and repair their house that affected by the flood. In that situation, if the society as the actors of $U M K M$ in watershed along Bengawan Solo while they also lose their consumer. It means that the disaster influences their activities, the loss of property, production and income in the community which at the end brought an impact on the condition of macro-economic (Ariviyanti \& Wisnu 2014, Triwidiyanto 2013).

It is natural that in the floods season, the actors of the $U M K M$ to experience a decrease in their business turnover and production activities. Meanwhile, when the business they managed declining, the business sites are damaged and the buyer down, what will happen next obviously is the declining of profit and income obtained by the home industries actors altogether. Of as many as 100 actors of $U M K M, 20 \%$ of respondents stated that capital owned shrank drastically after the disaster, and as many as $76 \%$ of respondents said they quiet feel the shrinking of the capital after the flood disaster that struck the business and the surrounding environment. Savings and capital owned, when a disaster occurs, will sooner or later be used to meet the needs of everyday life and to fulfill the needs of repairing the damaged business sites, so that at one point the capital used for business development was slowly drain. A number of respondents said that because of the disaster, their savings would usually be drained, and to restart their business, the most promising means is to find a loan or sell valuable goods still held for venture capital.

As Prasetyo (2010) studies conducted, it examines that the economic impacts suffered by the disasteraffected communities along the Bengawan Solo basin are damaged and the loss of assets and assets 
that make them lose their livelihoods as well as the turnover of businesses that have decreased due to soaring prices principal. The disaster has made them unable to start their business again and is prone to termination due to the work sector that depends on the natural conditions. So all they can do is resign to the circumstances.

Table 6.

Capital eradication and capital origin re-opening the business after the disaster

\begin{tabular}{|c|c|c|}
\hline \multirow{3}{*}{$\begin{array}{l}\text { How many percentage of the capital decline } \\
\text { when disaster strikes? }\end{array}$} & $0 \%-25 \%$ & $51 \%$ \\
\hline & $26 \%-50 \%$ & $28 \%$ \\
\hline & $<51 \%$ & $21 \%$ \\
\hline \multirow{5}{*}{$\begin{array}{l}\text { When the respondents start to re-opening } \\
\text { their business aftermath, where is the capital } \\
\text { come from? }\end{array}$} & Saving & $28 \%$ \\
\hline & Government help & $7 \%$ \\
\hline & Relatives help & $33 \%$ \\
\hline & Loan from a creditor informal institution & $27 \%$ \\
\hline & Loan from a creditor formal institution & $15 \%$ \\
\hline \multirow{3}{*}{$\begin{array}{c}\text { The difficulties when they want re-open their } \\
\text { home industries (UMKM) they managed after } \\
\text { the disaster }\end{array}$} & Difficult & $15 \%$ \\
\hline & Medium & $73 \%$ \\
\hline & Easy & $12 \%$ \\
\hline
\end{tabular}

How big is the shrinking capital after the disaster, it is relatively different among the UMKM actors one each other. Most of respondents (61\%) stated that the capital depreciation is not too large, or on average only under $25 \%$. However, as many as $28 \%$ of respondents claimed to experience a process of capital depreciation up to $26-50 \%$, and the concern is there are $21 \%$ of respondents who experience the process of capital depreciation up to $50 \%$ more.

From the results of in-depth interviews we figured out, to restart the opening of business, most respondents generally realize it is not possible to do it as fast as before the disaster happened. To re-establish the post-disaster recovery effort, as long as it is done slowly and restart on a small scale, according to most respondents $(73 \%)$ it is actually not too difficult. Only $15 \%$ of respondents admitted to having difficulty reopening their business after they were flooded, and $12 \%$ of respondents even stated it was easy. Although it does not necessarily mean that reopening their business is as easy as before the disaster, but in general with a little extra work, they claimed they can quickly reopening the business they manage after the disaster.

Out of the 100 actors of $U M K M$ who have been flood victims, as many as $28 \%$ admitted they can quickly re-open their business from the support of the remaining savings owned. Meanwhile, as many as $33 \%$ of respondents claimed to reopen its business thanks to the support of its relatives. Among rural communities, it is common for the role of relatives who are economically more established, usually as patrons who become shelter when they need help.

In the meantime, for respondents who no longer have residual savings and can no longer obtain relatives' support, the funding sources of capital they can access to reopen their business usually comes from government assistance $(7 \%)$ or from informal credit loans $(27 \%)$ even loans from formal credit institutions, such as $B P R$, Koperasi or banks $(15 \%)$. To the extent possible, respondents do expect to get non-burdensome capital assistance, which have fixes interest rates on soft loans or if they do not require to pay interest on the loan. However, if the ideal conditions are not expected to occur, then there is no other way, some respondents claimed to be forced to owe to various credit institutions even though it must be burdened with an aggravating lending rate.

To reopen the business they have been managed before, it is claimed by most of the respondents is not an easy thing. The difficulties often faced by respondents when they are willing to reopen their business are capital limitations $(70 \%)$, damaged land $(58 \%)$, and still a possible aftermath 
threat (90\%). Some respondents (28\%) also admitted difficulty to re-open their business because the equipment owned was damaged by flooding. To reopen their businesses, most respondents claimed to do it gradually.

Table 7.

The difficulties when they want to re-open their business they manage after the disaster

\begin{tabular}{lcc}
\hline \multicolumn{1}{c}{ The difficulties } & Yes & No \\
\hline Limited capital & $70 \%$ & $30 \%$ \\
Broken equipment & $28 \%$ & $72 \%$ \\
Damaged land & $58 \%$ & $42 \%$ \\
Rare raw material & $39 \%$ & $61 \%$ \\
The man power to repair the house & $12 \%$ & $88 \%$ \\
Cow buyer & $21 \%$ & $79 \%$ \\
Another aftermath threat & $70 \%$ & $10 \%$ \\
\hline
\end{tabular}

Table 8.

The condition and the opprtunity business development aftermath the disaster

\begin{tabular}{ccc}
\hline & Core family & $43 \%$ \\
People who helped the & Relatives & $37 \%$ \\
respondents to re-opening their & Local governments & $7 \%$ \\
business in the aftermath & Acquaintance & $13 \%$ \\
& Loan shark & $0 \%$ \\
\hline Post-disaster, how is the & More develop & $6 \%$ \\
development of the business you & Quite the same & $55 \%$ \\
managed? & Worse & $31 \%$ \\
\hline \multirow{2}{*}{ The opportunity to develop the } & Bright & $15 \%$ \\
business after the floods & So so & $53 \%$ \\
& Vague & $32 \%$ \\
\hline
\end{tabular}

Parties who have been much help when respondents tried to reopen the business, especially the core family $(43 \%)$ and support from the relatives $(37 \%)$. For the government role, this study found only a small proportion of respondents who received support from the government when they attempted to reopen their business $(7 \%)$.

In the aftermath of the disaster, sooner or later, the business condition of the respondents (55\%) will be the same as in the past. Nevertheless, as many as $31 \%$ of respondents admitted that their business condition is getting worse in the aftermath of the disaster. Unlike the period before the disaster, in the era of increasingly fierce business competition and the sluggishness of economic conditions as recently happened, it is difficult to expect their businesses can quickly recover.

Of the $100 U M K M$ actors studied, 53\% of respondents are optimistic about the opportunity to develop the business they manage after the ordinary disaster. However, as many as $32 \%$ of respondents admitted their business development prospects in the future tend to be bleak. Only $15 \%$ of respondents are still optimistic that their business can still be developed in the aftermath of the disaster. Quite a lot of respondents who are pessimistic about the development of their business in the future, because they realize the current and future economic conditions are still difficult to predict. The decline in people's purchasing power is one of the things that some respondents feel today.

In normal conditions, in fact many respondents claimed to be worried about the development of business they manage. Especially when they experience a disaster that makes their business as well as their business site damaged. The study found that the damage condition experienced in the aftermath 
of the disaster, the most severe is the cultivated land (35\%) and the location or business location (26\%). In addition, quite a lot of respondents also complained of severe damage to raw materials owned (14\%), and production equipment or machinery (15\%). Most respondents also complained of severe damage to their production facilities and infrastructure.

Table 9.

The damage condition experienced in the business assets owned

\begin{tabular}{lcccc}
\hline \multicolumn{1}{c}{ Business assets damage } & Yes, severe & $\begin{array}{c}\text { Yes, quite } \\
\text { severe }\end{array}$ & $\begin{array}{c}\text { Yes, not that } \\
\text { severe }\end{array}$ & No \\
\hline Cultivated land & $35 \%$ & $41 \%$ & $19 \%$ & $5 \%$ \\
Equipment/production & $15 \%$ & $21 \%$ & $19 \%$ & $45 \%$ \\
machinery & $26 \%$ & $21 \%$ & $40 \%$ & $13 \%$ \\
Location/business site & $14 \%$ & $24 \%$ & $29 \%$ & $33 \%$ \\
Raw material & $9 \%$ & $18 \%$ & $29 \%$ & $44 \%$ \\
Supporting facilities (table, etc) & &
\end{tabular}

By the conditions that forced them to retreat a few steps back as it is today, many respondents seem to be pessimistic that their business conditions can recover quickly. However, as with the UMKM actors in general, the resilience and endurance of $U M K M$ against various crisis pressures, including the pressures arising from the disaster, will undoubtedly be the capital to get out of this unbeneficial situation as soon as possible.

\section{Survival mechanism}

The actor of $U M K M$ who every year always experience as flood disaster, it certainly difficult for them to continue their proper life and their business. However, the experience has proved that the poor society and the actor of SMEs who lives along the river basin of Bengawan Solo generally own endurance and survival mechanism. The years of experience as flood victims seems made the SMEs actor turn into more resilient and not easily give up on the circumstances. Moreover, generally, they did not have any choice besides to stay in their region which disaster-prone and they have an attachment to their home (Ariviyanti \& Wisnu 2014).

There are several survival mechanisms that usually done by the disaster victims both in economic, structural or social. In economic were usually done by focusing on the efforts to gain another income resource outside their main job. In structural were done by reducing the loss and minimalize the risks by technology application. Meanwhile, in social, it focuses on social activities such as help each other and other groups activities (Setiawan 2014).

On paper, the UMKM actors who are always be the victims almost every year due to the flood disaster, it is of course difficult hoping they can carry out their life and business well. However, experience has proven that the poor and $U M K M$ actors living along the Bengawan Solo basin generally have their own effective survival and survival mechanisms. Years of experience of being a victim of a flood disaster seems to make UMKM actors more resilient and not easily give up on the situation.

From a previous study by experts, the mechanisms normally developed by poor families to maintain their survival are: First, household members diversify their activities. The most degrading work was accepted, despite the low pay. If these activities are still inadequate, they will turn to the existing support systems in the village. Second, work more with less income. Basically this means reducing food consumption and other basic ingredients (Korten 1988: 188-189). In addition, the pattern of survival strategies developed by poor families is generally concentrically patterned. To overcome the crisis or economic pressure experienced by poor families, firstly they always try to overcome them independently. Some self-employed efforts are usually utilize family members, both children and wives to seek additional income (Wignjosoebroto \& Suyanto 2008: 66). If the independent business is no longer reliable, then they will look and expect support from relatives as an alternative effort so that they will not be crushed by the crisis pressure. 
Table 10.

The effort to fix the damage happened after the disaster

\begin{tabular}{lccc}
\hline \multicolumn{1}{c}{ The efforts has been done } & Often & Seldom & Never \\
\hline Asking for help from core family & $50 \%$ & $47 \%$ & $3 \%$ \\
Asking for help from relatives & $48 \%$ & $39 \%$ & $13 \%$ \\
Rely on government suppport & $9 \%$ & $15 \%$ & $76 \%$ \\
Rely on generous help & $0 \%$ & $0 \%$ & $100 \%$ \\
Fix it by their own gradually & $100 \%$ & $0 \%$ & $0 \%$ \\
\hline
\end{tabular}

The study found that the efforts of $U M K M$ actors who are victims of the flood disaster to get out of the stresses and crises experienced are often by asking for the help from the core families $(50 \%)$, asking for relatives (48\%), or if as far as possible, they will generally improve themselves gradually according to ability (100\%). Of the 100 respondents surveyed, only $9 \%$ of respondents claimed to usually request and rely on government assistance to repair the damage that occurred after the disaster.

Table 11.

Survival mechanism developed to re-open business they managed (UMKM) aftermath the disaster

\begin{tabular}{lcc}
\hline \multicolumn{1}{c}{ Survival mechanism developed } & Yes & No \\
\hline Re-open small scale business & $51 \%$ & $49 \%$ \\
Work harder & $70 \%$ & $30 \%$ \\
Looking for soft-loan & $58 \%$ & $42 \%$ \\
Prepared saving in advance & $21 \%$ & $79 \%$ \\
\hline
\end{tabular}

In order to revive the efforts that have been undertaken before the disaster, the mechanism developed by most respondents is generally by trying to work harder (70\%), seeking soft loans (58\%) for capital to rebuild their business, and trying to restart their business even in a small-scale (51\%). Among rural people, hard work is a common thing they do to survive.

Table 12.

Survival mechanism aftermath the disaster

\begin{tabular}{ccc}
\hline & $\begin{array}{c}\text { Looking for a capital loan to develop business } \\
\text { they have managed }\end{array}$ & $74 \%$ \\
The effort made after the disaster & Looking for another job & $12 \%$ \\
Let it go & $14 \%$ \\
\hline $\begin{array}{c}\text { If there could be a disaster again, } \\
\text { what do you do? }\end{array}$ & Don't know yet & $9 \%$ \\
\hline $\begin{array}{l}\text { Whether the respondents have no } \\
\text { plan to relocate their business site } \\
\text { in a less risk flood place? }\end{array}$ & Prepared in advance & $31 \%$ \\
\hline
\end{tabular}

Among the $U M K M$ actors, looking for capital loans for new business start-up, seems to be the most common way. This study found that $74 \%$ of respondents said they would try to find a capital loan (soft) to start the business after the disaster. However, as many as $12 \%$ of respondents admitted trying to find new jobs after the disaster, while $14 \%$ of respondents admitted resigned to fate-without doing a significant means to restore and revive the old effort.

When the prospect to expand the business is believed to be still there, then a respondent will try to rebuild his business from the bottom. However, when they feel there is no opportunity to restart their businesses, then the mechanism is trying to find another job to survive the survival of his family. 
What is meant by finding a new job here can be done in the respondent's village, or if necessary they will go to a big city, working their way in the urban informal sector to patch up the necessities of life after the disaster.

Most of the resident who is the annual victims of the flood disaster over the years, most respondents $(60 \%)$ have actually tried to prepare themselves before the disaster actually occurred. However, when disaster suddenly struck, a number of respondents said that the impact often remains unanticipated. When the overflow water floods the house, the land and the respondent's business sites, what can be done by the victims are minimize the impact as well as reducing the loss and suffer as small as they can, so that the burden not too much.

Almost all of respondents are resigned or at least do not try to get out of their area to avoid flooding. Most respondents (88\%) admitted resigned to accept fate and did not have any plan to move to another location that is less risk of flooding. Meanwhile, as many as $15 \%$ of respondents actually want to move, but realize they do not have enough funds for it. Only $3 \%$ of respondents planned to move and have prepared funds to do so.

Among respondents who are economically have more saving, because of the support from their relatives, they do have an opportunity to move and develop a business in a new place. However, most $U M K M$ actors studied are economically poor, so what can be done is generally trying to stay afloat even if you have to face the pressure to fulfil the basic need for life.

\section{Conclusion}

Disaster, in any form - including in the form of floods caused by the overflowing of the Bengawan Solo River - is often an annual problem faced by the UMKM in the disaster prone areas such as Bojonegoro and Lamongan districts. In these two areas, the overflow of the Sungai Bengawan River not only damages productive agricultural lands, but also causes some of the UMKM actors to experience barriers in carrying out their business. Floods that capture the homes of residents as well as their businesses, not only damage the production equipments and raw materials altogether, but also it is cause the production activities to be temporarily stopped.

The efforts to re-empower $U M K M$ in Bojonegoro and Lamongan post disaster, is not an easy things to do. The efforts to empower $U M K M$ in disaster prone areas cannot be done by relying on a charitable programs and activities, but most importantly is how to awaken, give opportunities and empower $U M K M$ actors in the real sense.

Various forms of dependence on $U M K M$ and their debt trap and poverty pressures should not only be reduced but most importantly we also need to find a substitution institution that can fulfill the needs of $U M K M$ in terms of capital, fulfillment of raw materials and marketing. Some of the recommendations that need to be underlined here in order to accelerate efforts to empower UMKM and encourage the development of economic enterprises are as follows:

Firstly, to overcome the difficulties of capital which often faced by the UMKM actors who become victims of disaster, increasing the institutional capacity and quality of service of local financial institution in providing alternative funding source for $U M K M$ with less difficult procedure is clearly needed un this case, supporting network among financial institution micro (MFI) and between MFIs as well as the Banks also needed to be developed.

Secondly, to encourage the independence growth of $U M K M$ actors after the disaster, in the future should also be developed various efforts to eliminate the dependency of marketing that has been controlled by intermediary traders or collectors by finding an alternative markets facilitated by the government or establish a buffer institution which can escort so that the result product by UMKM can be valued accordingly in accordance with the fair market mechanisms. In order to strengthen the bargaining position of $U M K M$ actors, not only training and mentoring to empower the business 
sectors, but also training and mentoring to empower the development of social capital of $U M K M$ actors through poverty eradication program that encourages the growth of the ability of $U M K M$ to do diversification business and overcome their vulnerability so that they will not easily get trapped in burdensome debt.

Another recommended form of scheme here can be a direct subsidy to the poor UMKM actors who are victims of disasters so that they can revive after the loss of their business by developing a prosperous savings program for $U M K M$ and an alternative social insurance programs for $U M K M$ actors after the disaster. For instance, in procurement of raw materials, what is required by $U M K M$ except or the certainty or price stability, it is also need the adequate production cost and proportional to the profits obtained.

Third, encouraging and facilitating the growth of business networks and business partnership patterns that are more favorable to the interests of $U M K M$ who are victims of disasters, and at the same time to prevent the $U M K M$ actors not become victims of exploitation which causes the $U M K M$ actors get an incomparable profit margin compare to the production costs they have spent.

Fourth, the development of $U M K M$ disaster victims based on production asset assistance pattern. What is meant by the development of $U M K M$ based on production assets here is the provision of assistance to $U M K M$ who are victims of disasters which is not manifested as business capital, but more in the form of sustainable production assets.

Fifth, the development of production cost efficiency as well as UMKM management that is more organized and standardized. The program developed can be training of production process efficiency, donating supporting equipment that can be useful to reduce production cost, or management training program in managing the $U M K M$ which is really contextual and benign to encourage the efficiency of $U M K M$ actors who become victims of disaster, and also to guarantee the standardization of UMKM products to keep their quality in order to improve the competitiveness of $U M K M$ products in a wider and more competitive market.

To see how effective the various suggestions suggested, a field test is undeniably need to be tested. More importantly, whatever programs being developed, it has to put the UMKM actors especially they are whose victims of disaster as a top priority.

\section{References}

Adi S (2013) Karakteristik bencana banjir bandang di Indonesia. Jurnal Sains dan Teknologi Indonesia, 15 (1):42-51.

Ariviyanti N \& Wisnu P (2014) Faktor-faktor yang meningkatkan resiliensi masyarakat dalam menghadapi bencana ROB di Kelurahan Tanjung Emas Semarang. Jurnal Teknik PWK, 3 (4):991-1000.

Firdaus A (2011) Dampak sosial ekonomi terhadap masyarakat sekitar Situ akibat musibah Situ Gintung. Skripsi, UIN Syarif Hidayatullah, Jakarta.

Habibi M \& Buchori I (2013) Model spasial kerentanan sosial ekonomi dan kelembagaan terhadap bencana Gunung Merapi. Jurnal Teknik PWK, 2 (1):1-10.

Habibullah (2013) Kebijakan penanggulangan bencana berbasis komunitas: Kampung siaga bencana dan desa/kelurahan tangguh bencana. Informasi, 18 (2):133-150.

Hendrawan D (2005) Kualitas air sungai dan situ di Jakarta. Makara, Seri Teknologi, 9 (1):13-19.

Korten DC \& Sjahrir (1988) Pembangunan Berdimensi Kerakyatan. Jakarta: Yayasan Obor Indonesia. 
Mustain M \& Udji Asiyah (2014) Model Pemberdayaan Keluarga Miskin di Daerah Rawan Bencana. Surabaya: Universitas Airlangga.

Prasetyo RA (2010) Masyarakat korban bencana. Dialektika, 5 (2).

Sesunan D (2014) Analisis kerugian akibat banjir di Bandar Lampung. Jurnal Teknik Sipil UBL, 5 (1):559-584.

Setiawan H (2014) Analisis tingkat kapasitas dan strategi copig masyarakat lokal dalam menghadapi bencana longsor-studi kasus di Tawangmang, Karanganyar, Jawa Tengah. Jurnal Penelitian Sosial dan Ekonomi Kehutanan, 11 (1):70-81.

Srihartini (2010) Membangun masyarakat sadar bencana. Jurnal Dakwah, 11 (2):157-171.

Suganda E, Yatmo YA \& Atmodiwirjo P (2009) Pengelolaan lingkungan dan kondisi masyarakat pada wilayah hilir sungai. Makara, Sosial Humaniora, 13 (2):143-153.

Triwidiyanto A \& Navastara AM (2013) Pemintakatan risiko bencana banjir akibat luapan Kali Kemuning di Kabupaten Sampang. Jurnal Teknik Pomits, 2 (1):43-47.

Wignjosoebroto S \& Suyanto B (eds) (2008) Bencana di Jawa Timur: Dampak dan Upaya Penanggulangannya. Surabaya: Dewan Pakar provinsi Jawa Timur. 